\title{
CUX1 Gene
}

National Cancer Institute

\section{Source}

National Cancer Institute. CUX1 Gene. NCI Thesaurus. Code C95578.

This gene is involved in both transcriptional regulation and Golgi vesicle transport. 